\title{
EFEKTIVITAS PEMBELAJARAN KOOPERATIF TIPE STAD PADA MATERI POKOK PERBANDINGAN DI SMPN II MEGALUH JOMBANG
}

\author{
Oleh: Rifa Nurmilah dan Abdul Rozak \\ STKIP PGRI Jombang
}

\begin{abstract}
Abstrak:
Tujuan penelitian ini adalah: 1) menjelaskan efektivitas penerapan pembelajaran kooperatif tipe STAD pada materi pokok Perbandingan; 2) menjelaskan apakah hasil belajar yang mengikuti pembelajaran kooperatif tipe STAD lebih baik di bandingkan dengan hasil belajar siswa yang mengikuti pembelajaran secara biasa/konvensional untuk materi pokok Perbandingan. Penelitian ini adalah penelitian eksperimen semu, sampel penelitian siswa kelas VIIA sebagai kelas eksperimen dan kelas VIIB sebagai kelas kontrol. Berdasarkan hasil analisis deskriptif diperoleh bahwa pembelajaran Kooperatif Tipe STAD pada materi pokok Perbandingan di SMPN 2 Megaluh dikatakan efektif dengan kriteria (1) ketuntasan belajar secara klasikal tuntas sebanyak 87,09\%, (2) aktivitas siswa efektif (3) kemampuan guru dalam mengelola pembelajaran efektif (4) Respon siswa positif terhadap pembelajaran. Berdasarkan hasil analisis inferensial uji $t$ dengan taraf signifikan 5\% diperoleh thitung $=2,197$ dan $t_{\text {tabel }}=2,000$ karena $t_{\text {hitung }}>t_{\text {tabel }}$ maka Hi diterima, artinya hasil belajar siswa dengan pembelajaran kooperatif tipe STAD lebih baik daripada siswa yang mendapatkan pembelajaran biasa/konvensional di SMPN II Megaluh Jombang tahun pelajaran 2013/2014.
\end{abstract}

Kata Kunci: Efektif, Pembelajaran Kooperatif Tipe STAD, Perbandingan

\section{Pendahuluan}

Matematika sebagai salah satu ilmu dasar mempunyai peranan yang sangat penting dalam kehidupan sehari-hari serta dalam kemajuan ilmu pengetahuan dan teknologi pada umumnya. Oleh karena itu matematika merupakan salah satu mata pelajaran pokok di sekolah baik di sekolah dasar, sekolah lanjutan sampai dengan perguruan tinggi. Matematika perlu dipelajari oleh siswa karena matematika merupakan sarana berpikir untuk menumbuhkembangkan pola berpikir logis, sistematis, objektif, kritis dan rasional.

Harus diakui bahwa pembelajaran matematika yang selama ini dilaksanakan di jenjang sekolah ternyata belum memaksimalkan pencapaian tujuan pendidikan matematika. Keabstrakan objek matematika dan pendekatan 
pembelajaran yang kurang tepat, menjadi faktor penyebab sulitnya matematika bagi para siswa. Mereka merasa apa yang dipelajari kurang bermanfaat dalam kehidupan seharihari, sehingga mereka merasa dipaksa untuk menerima atau mempelajari sesuatu yang berada di luar jangkauan daya pikirnya.

Salah satu upaya yang dapat dilakukan untuk memperbaiki kualitas pendidikan adalah pembaharuan kurikulum menjadi kurikulum tingkat satuan pelajaran. Untuk mewujudkan kecakapan dan kemahiran matematika sesuai dengan tujuan kurikulum tersebut, perlu diterapkan prinsip pendidikan yang tidak hanya berorientasi pada bidang akademik semata, tetapi bagaimana seorang siswa dengan hasil belajar yang dicapai dapat menerapkannya dalam kehidupan sehari-hari. Siswa harus diupayakan menjadi subjek belajar yang aktif mengkonstruk atau membangun sendiri pemahaman terhadap materi yang dipelajari, sedangkan guru sebaiknya berperan sebagai fasilitator dan mediator yang kreatif agar siswa dapat belajar dalam suasana yang menyenangkan.

Pembelajaran kooperatif tipe Student Teams Achievement Division (STAD) sesuai dengan hal tersebut, karena dalam pembelajaran kooperatif tipe STAD siswa diberi kesempatan untuk berinteraksi dengan siswa lainnya serta dapat memecahkan masalah sesuai dengan pengetahuan dan kemampuan yang dimilikinya. Pembelajaran kooperatif tipe STAD merupakan tipe pembelajaran yang memberikan keleluasaan siswa berpikir secara aktif, sehingga dapat memecahkan permasalahan matematika melalui kerja sama siswa. Model pembelajaran merupakan salah satu faktor yang penting dalam meningkatkan suatu hasil belajar matematika. Slavin (dalam Trianto, 2009 : 56) menyatakan bahwa pada STAD siswa ditempatkan dalam tim belajar beranggotakan 4-5 orang yang merupakan campuran menurut tingkat prestasi, jenis kelamin, dan suku.

Salah satu materi matematika yang diajarkan di SMP/MTs kelas VII adalah materi pokok "Perbandingan". Materi ini sering muncul dan digunakan dalam kehidupan sehari-hari. Dengan menerapkan pembelajaran kooperatif tipe STAD dalam pembelajaran matematika di sekolah diharapkan dapat meningkatkan pemahaman dan 
penguasaan siswa terhadap materi, karena pembelajaran kooperatif tipe STAD dalam pelaksanaannya yaitu presentasi kelas, kegiatan kelompok, melaksanakan evaluasi dan penghargaan kelompok. Pembelajaran dilakukan secara berkelompok dengan menggunakan lembar kegiatan atau perangkat pembelajaran lain, siswa bekerja secara berdiskusi untuk menuntaskan materi. Mereka saling membantu untuk memahami bahan pelajaran, sehingga dipastikan semua anggota kelompok telah mempelajari materi tersebut secara tuntas.

Berdasarkan hasil wawancara guru sebelumnya di SMPN 2 Megaluh diperoleh informasi bahwa pembelajaran matematika di sekolah masih menggunakan pembelajaran biasa sehingga banyak siswa merasa kurang senang dan motivasi belajar rendah untuk belajar matematika. Jika motivasi belajar siswa rendah tentunya akan berimbahas terhadap hasil belajar yang dicapai. Dengan dasar itu, peneliti termotivasi untuk melakukan penelitian dalam perbaikan pembelajaran yang masih berlaku dengan menerapkan pembelajaran koperatif tipe STAD untuk materi pokok Perbandingan. Hal baru yang disajikan dalam penelitian ini adalah pengembangan perangkat rencana pembelajaran yang disajikan untuk guru, bertujuan supaya guru dapat mengelola kelas dan melaksanakan pembelajarannya lebih bermakna dan menyenangkan. Sehingga nantinya siswa dapat belajar secara bertahap mengkonstruk pengetahuanya sendiri. Berdasarkan latar belakang tersebut peneliti termotivasi untuk menerapkan pembelajaran kooperatif tipe STAD pada materi pokok Perbandingan di SMPN II Megaluh Jombang.

Berdasarkan latar belakang masalah yang telah dikemukakan di atas, maka rumusan masalah dalam penelitian ini sebagai berikut:

1. Apakah pembelajaran kooperatif tipe STAD efektif untuk mengajarkan materi pokok Perbandingan?

2. Apakah hasil belajar siswa yang mengikuti pembelajaran kooperatif tipe STAD lebih baik dibandingkan dengan hasil belajar siswa yang mengikuti pembelajaran konvensional/biasa untuk materi pokok Perbandingan? 


\section{Tinjauan Pustaka}

Pembelajaran merupakan inti dari proses pendidikan di sekolah dengan melibatkan guru dan siswa yang melakukan aktivitas belajar dan mengajar. Menurut Dimyati dan Mudjiono (2006:157) pembelajaran juga merupakan proses yang diselenggarakan oleh guru untuk membelajarkan siswa dalam belajar, bagaimana belajar memperoleh dan memproses pengetahuan, keterampilan dan sikap. Gagne, Briggs, dan Wager (Udin S, Winataputra, dkk., 2008:119) menyatakan bahwa pembelajaran adalah serangkaian kegiatan yang dirancang untuk memungkinkan terjadinya proses belajar pada siswa. Menurut Degeng (Ratumanan, 2004:3) menyatakan bahwa pembelajaran adalah kegiatan memilih, menetapkan dan mengembangkan metode untuk mencapai hasil yang diinginkan. Dalam hubunganya dengan pelajaran matematika, Nikson (Ratumanan, 2004:3) mengemukakan bahwa pembelajaran matematika adalah suatu upaya membantu siswa untuk mengkontruksi (membangun) konsep-konsep atau prinsip-prinsip matematika dengan kemampuannya sendiri melalui proses internalisasi sehingga konsep atau prinsip itu terbangun kembali. Berdasarkan pengertian tersebut dapat disimpulkan bahwa pembelajaran matematika sebagai suatu proses membangun pemahaman siswa dimana terjadi interaksi dalam pembelajaran matematika yang meliputi interaksi antara siswa dan guru.

Persiapan - persiapan yang dilakukan sebelum pelaksanaan pembelajaran kooperatif tipe STAD, (Trianto, 2009: 69) yaitu:

\section{Perangkat pembelajaran}

Sebelum melaksanakan kegiatan pembelajaran ini perlu dipersiapkan perangkat pembelajaran, yaitu meliputi rencana pembelajaran, Lembar Kerja Siswa (LKS) beserta lembar jawabannya, dan kuis.

\section{Membentuk kelompok kooperatif}

Menentukan anggota kelompok diusahakan agar kemampuan siswa dalam kelompok adalah heterogen dan kemampuan antara satu kelompok lainya relatif homogen. Apabila memungkinkan kelompok kooperatif perlu memperhatikan ras, agama, jenis kelamin, dan latar belakang sosial. Apabila dalam kelas terdiri atas ras, dan latar belakang yang relatif sama, maka pembentukan 
kelompok dapat didasarkan pada prestasi akademik, yaitu siswa dalam kelas terlebih dahulu dirangking sesuai kepandaian dalam mata pelajaran matematika. Tujuannya adalah untuk mengurutkan siswa sesuai dengan kemampuan matematika dan digunakan untuk mengelompokkan siswa dalam kelompok.

\section{Menentukan skor awal}

Skor awal yang dapat digunakan dalam kelas kooperatif adalah nilai ulangan sebelumnya. Skor awal ini dapat berubah setelah ada kuis. Misalnya pada pembelajaran lebih lanjut dan setelah ada kuis. Misalnya pada pembelajaran lebih lanjut dan setelah diadakan tes, maka hasil tes masingmasing individu dapat dijadikan skor awal.

4. Pengaturan tempat duduk

Pengaturan tempat duduk dalam kelas kooperatif perlu diatur dengan baik untuk menunjang keberhasilan pembelajaran kooperatif apabila tidak ada pengaturan tempat duduk dapat menimbulkan kekacauan yang menyebabkan gagalnya pembelajaran pada kelas kooperatif.

5. Kerja kelompok

Untuk mencegah adanya hambatan pada pembelajaran kooperatif tipe STAD, terlebih dahulu diadakan latihan kerjasama kelompok. Hal ini bertujuan untuk lebih jauh mengenal masing-masing individu dalam kelompok.

Langkah-langkah model pembelajaran STAD, sebagai berikut :

1) Menyampaikan tujuan dan memotivasi siswa

Guru menyampaikan semua tujuan pelajaran yang ingin dicapai pada pelajaran tersebut dan memotivasi siswa.

2) Menyajikan/menyampaikan informasi.

Guru menyajikan informasi kepada siswa dengan jalan mendemonstrasikan atau lewat bahan bacaan.

3) Mengorganisasikan siswa dalam kelompok belajar

Guru menjelaskan kepada siswa bagaimana caranya membentuk kelompok belajar dan membantu sikap kelompok agar melakukan transisi secara efisien.

4) Membimbing kelompok bekerja dan belajar Guru membimbing kelompok-kelompok belajar pada saat mereka mengerjakan tugas mereka.

5) Memberikan penghargaan

Guru mencari cara untuk menghargai baik upaya maupun hasil belajar individu dan kelompok. 


\section{Aktivitas siswa}

Aktivitas siswa merupakan prinsip penting dalam interaksi mengajar belajar. Selama proses pembelajaran berlangsung, siswa tidak hanya mendengarkan sejumlah teori-teori secara pasif melainkan terlibat aktif dan sungguhsungguh dalam semua kegiatan pembelajaran.

Untuk melihat akivitas siswa dalam proses pembelajaran diperlukan indikator. Melalui indikator tersebut dapat dilihat tingkah laku mana yang muncul dalam proses pembelajaran berdasarkan apa yang telah dirancang oleh guru. Tingkah laku yang dimaksud adalah:

1) Mendengarkan/ memperhatikan penjelasan guru/ teman.

2) Membaca/ mengerjakan LKS/ materi ajar.

3) Menulis yang relevan dengan kegiatan pembelajaran.

4) Berdiskusi/ bertanya antar siswa dan guru.

5) Mengkomunikasikan hasil kerja kelompok.

6) Mengerjakan kuis.

7) Perilaku yang tidak relevan dengan kegiatan pembelajaran, seperti percakapan masalah di luar pembelajaran, berjalan-jalan di luar kelompoknya, mengerjakan sesuatu di luar topik pembelajaran, dan lainlain.

2. Pengelolaan Pembelajaran

Proses pembelajaran dapat berjalan dengan baik, maka seorang guru sebagai salah satu komponen yang sangat berpengaruh terhadap keberhasilan pembelajaran harus memiliki kemampuan yang memadai dalam mengelola pembelajaran. Kemampuan-kemampuan yang dimaksud antara lain: kemampuan penguasaan materi pelajaran, pemilihan pendekatan pembelajaran yang tepat, pemilihan sarana prasarana yang mendukung terlaksananya proses pembelajaran. Aspek-aspek dari kemampuan tersebut dituangkan dalam Rencana Pembelajaran (RP) yang akan dilaksanakan pada saat proses pembelajaran berlangsung.

Dalam proses pembelajaran, seorang guru harus menyadari bahwa mengajar bukanlah berarti mentransfer pengetahuan dari orang yang sudah tahu (guru) kepada yang belum tahu (siswa), melainkan guru berperan sebagai mediator dan fasilitator dalam membantu siswa untuk mengkonstruksi sendiri pengetahuannya lewat kegiatannya terhadap fenomena dan objek yang ingin diketahui, dan memberikan petunjuk sewaktu-waktu diperlukan. 
Dari uraian di atas maka kemampuan guru mengelola pembelajaran yang dimaksud adalah keterampilan guru dalam menerapkan serangkaian kegiatan pembelajaran matematika dengan pembelajaran kooperatif tipe STAD yang telah dirancang dalam RP.

\section{Respon Siswa}

Salah satu faktor yang berpengaruh terhadap keberhasilan proses pembelajaran adalah respon siswa. Faktor diri siswa yang berpengaruh terhadap proses pembelajaran tersebut antara lain adalah bakat, minat, kemampuan, dan motivasi untuk belajar. Motivasi dipandang sebagai suatu proses dalam diri siswa yang menyebabkan munculnya tingkah laku ke arah tujuan yang diharapkan. Motivasi dibedakan atas motivasi instrinsik dan motivasi ekstrinsik. Motivasi instrinsik merupakan motivasi yang berasal dari dalam diri siswa. Sebaliknya, motivasi ekstrinsik berasal dari luar diri siswa.

Siswa yang termotivasi secara instrinsik akan melakukan tugas-tugas pembelajaran dan selalu ingin mempelajari bahan-bahan pelajaran dengan senang hati tanpa merasa terpaksa. Sedangkan siswa yang termotivasi ekstrinsik diartikan sebagai siswa mendapat dorongan dari luar untuk mencapai tujuan pembelajaran. Misalnya, selain karena ingin lulus ujian, seorang siswa belajar dengan giat karena ingin memperoleh hadiah atau penghargaan dari orang tuanya.

Berdasarkan uraian diatas, maka dapat disimpulkan bahwa seorang siswa yang mempunyai motivasi tinggi dalam belajar matematika akan memberikan respon positif dan sebaliknya siswa yang motivasi belajarnya rendah akan memberikan respon negatif yang diwujudkan dalam sikap atau pendapat yang diberikan terhadap proses pembelajaran yang sedang berlangsung.

Adapun respon siswa terhadap pembelajaran yang dimaksud adalah pendapat atau tanggapan siswa terhadap pelaksanaan pembelajaran matematika dengan pembelajaran kooperatif tipe STAD. Indikator yang digunakan untuk mengungkap respon siswa terhadap pembelajaran adalah penilaian siswa berdasarkan perasaan, pendapat, minat dan komentar siswa. Penilaian siswa tersebut meliputi: 
1) Perasaan (senang/ tidak senang) terhadap komponen mengajar, yang meliputi: suasana belajar di kelas/ cara belajar dan cara guru mengajar.

2) Pendapat (baru/ tidak baru) terhadap komponen mengajar, yang meliputi: suasana belajar di kelas/ cara belajar dan cara guru mengajar.

3) Minat (berminat/ tidak berminat) untuk mengikuti pembelajaran matematika dengan pembelajaran kooperatif tipe STAD pada proses pembelajaran berikutnya.

4) Komentar (mudah/ sedang/ sulit) dalam memahami materi pelajaran dengan menggunakan pembelajaran kooperatif tipe STAD.

4. Hasil Belajar

Hasil belajar adalah pola-pola perbuatan, nilai-nilai, pengertian-pengertian, sikap-sikap, apresiasi dan keterampilan-keterampilan. Merujuk pemikiran Gagne, hasil belajar berupa :

1) Informasi verbal yaitu kapabilitas mengungkapkan pengetahuan dalam bentuk bahasa, baik lisan maupun tulisan. Kemampuan merespons secara spesifik terhadap rangsangan spesifik. Kemampuan tersebut tidak memerlukan manipulasi simbol, pemecahan masalah maupun penerapan aturan.

2) Keterampilan intelektual yaitu kemampuan mempresentasikan konsep dan lambang. Keterampilan intelektual terdiri dari kemampuan mengkategorisasi, kemampuan analitis-sintesis fakta-konsep dan mengembangkan prinsip-prinsip keilmuan. Keterampilan intelektual merupakan kemampuan melakukan aktivitas kognitif bersifat khas.

3) Strategi kognitif yaitu kecakapan menyalurkan dan mengarahkan aktivitas kognitifnya sendiri. Kemampuan ini meliputi penggunaan konsep dan kaidah dalam memecahkan masalah.

4) Keterampilan motorik yaitu kemampuan melakukan serangkaian gerak jasmani dalam urusan dan koordinasi, sehingga terwujud otomatisme gerak jasmani.

5) Sikap adalah kemampuan menerima atau menolak objek berdasarkan penilaian terhadap objek tersebut. Sikap berupa kemampuan menginternalisasi dan eksternalisasi 
nilai-nilai. Sikap merupakan kemampuan menjadikan nilai-nilai sebagai standar perilaku.

Menurut Bloom, hasil belajar mencakup kemampuan kognitif, efektif, dan psikomotorik. Domain kognitif adalah knowledge (pengetahuan, ingatan), comprehension (pemahaman, menjelaskan, meringkas, contoh), application (menerapkan), analysis (menguraikan, menentukan hubungan), synthesis (mengorganisasikan, merencanakan, membentuk bangunan baru), evaluation (menilai). Domain efektif adalah receiving (sikap menerima), responding (memberikan respons), valving (nilai), organization (organisasi), characterization (karakterisasi). Domain psikomotor juga mencakup keterampilan produktif, teknik, fisik, sosial, manajerial, dan intelektual. Sementara, menurut Lindgren hasil pembelajaran meliputi kecakapan, informasi, pengertian, dan sikap.

Hasil belajar adalah perubahan perilaku secara keseluruhan bukan hanya salah satu aspek potensi kemanusiaan saja. Artinya, hasil pembelajaran yang dikategorisasi oleh para pakar pendidik sebagaiman tersebut diatas tidak dilihat secara fragmentaris atau terpisah, melainkan koprehensif. (Suprijono, 2009:7 )

\section{Metode Penelitian}

Jenis penelitian dalam penelitian ini adalah penelitian eksperimen yang diawali dengan pengembangan perangkat Rencana Pembelajaran (RP) yang bertujuan agar dalam pengelolan kelas sesuai dengan pembelajaran kooperatif tipe STAD. Dalam penelitian ini, tidak semua variabel dapat dikontrol dengan ketat. Ada beberapa variabel yang sebenarnya berpengaruh terhadap hasil penelitian, tetapi tidak dapat dikontrol secara menyeluruh. Karena itu penelitian digolongkan dalam penelitian eksperimen semu. Rancangan penelitian ini menggunakan model pretestposttest only control design. Dalam penelitian kedua kelas di beri tes dengan tes yang sama sebagai tes akhir. Hasil kedua tes akhir tersebut akan dibandingkan.

Penelitian ini dilaksanakan di kelas VII SMPN 2 Megaluh Jombang Tahun pelajaran 2013/2014. Populasi penelitian adalah seluruh siswa kelas VII, selanjutnya akan dipilih dua kelas secara acak sebagai sampel. Kelas VIIA sebagai kelas eksperimen yaitu kelas yang diajar menggunakan 
pendekatan pembelajaran koperatif tipe STAD dan kelas VIIB sebagai kelas kontrol yaitu kelas yang diajar dengan menggunakan pembelajaran konvensional/biasa sebagaimana biasa dilaksanakan gurunya.

Instrumen pada penelitian ini terdiri dari: (1) lembar observasi aktivitas siswa, (2) lembar observasi (pengamatan) pengelolaan pembelajaran, (3) lembar keterampilan kooperatif siswa, (4) angket respon siswa (5) tes hasil belajar. Teknik analisis data yang digunakan adalah statistik deskriptif.

1) Analisis Data Aktivitas Siswa: Analisis hasil pengamatan terhadap aktivitas siswa meliputi menghitung frekwensi rata-rata tiap aspek tiap pertemuan dilakukan dengan cara menjumlahkan frekwensi aspek yang dimaksud di bagi banyak siswa yang diamati. Keefektivan aktivitas siswa tercapai untuk setiap rencana pembelajaran (RP) bila setiap aspek aktivitas siswa berada pada kriteria efektif yang ditetapkan.

2) Analisis Data Pengelolaan Pembelajaran: Data tentang kemampuan guru dalam menerapkan skenario pembelajaran matematika dengan pembelajaran kooperatif tipe STAD yang diamati oleh seorang pengamat, dianalisis menggunakan statistik deskriptif dengan skor rata-rata. Kemampuan guru mengelola pembelajaran dikatakan efektif jika skor dari setiap aspek untuk tiap rencana pembelajaran (RP) dinilai berada pada kategori cukup baik atau baik.

3) Analisis Keterampilan Kooperatif Siswa: untuk menghitung frekwensi dan persentase rata-rata tiap aspek keterampilan kooperatif siswa dihitung berdasarkan langkah-langkah sebagai berikut:

a) Rata-rata setiap aspek keterampilan kooperatif siswa pada masing-masing pertemuan, dihitung dengan menjumlahkan frekwensi setiap aspek yang muncul pada setiap siswa yang diamati kemudian dibagi banyaknya siswa yang diamati.

b) Persentase setiap aspek keterampilan kooperatif siswa pada masing-masing pertemuan, dihitung dengan membagi rata-rata setiap aspek yang muncul dengan jumlah frekwensi maksimal setiap aspek dikalikan $100 \%$. 
37 | al-Khwarizmi, Volume II, Edisi I, Maret 2014, Hal. 27 - 40

Sebagai kriteria, pembelajaran dikatakan efektif ditinjau dari keterampilan kooperatif siswa apabila semua aspek untuk tiap rencana pembelajaran (RP) berada pada kriteria batasan efektif. Selain itu perlu dilakukan revisi pada perangkat pembelajaran.

4) Analisis Data Respon Siswa: Data hasil angket respon siswa dianalisis dengan menentukan persentase jawaban siswa untuk tiap aspek respon positif. Persentase setiap aspek positif yang dinilai ditentukan dengan cara membagi banyaknya siswa yang memberikan tanggapan positif tiap aspek dengan banyaknya siswa dikalikan 100\%. Respon siswa dikatakan positif jika persentase untuk tiap aspek dalam kategori senang, baru, dan ya lebih dari atau sama dengan $75 \%$. Hasil analisis tersebut akan digunakan untuk merevisi perangkat pembelajaran.

5) Analisis Tes Hasil Belajar: Instrumen tes Hasil Belajar yang digunakan dalam penelitian ini jika memiliki validitas tes yang validitasnya minimal berada dalam kategori cukup, koefesien reliabilitas tes minimal berada pada kategori cukup.

\section{Hasil dan Pembahasan}

A. Deskripsi Hasil Pengembangan Perangkat Rencana Pembelajaran

Hasil pengembangan perangkat Rencana Pembelajaran (RP) pada umumnya validator menyatakan rencana Pembelajaran (RP) baik dan dapat digunakan dengan sedikit revisi. Berdasarkan hasil validasi, beberapa revisi yang dilakukan terhadap RP dapat dilihat pada table 1. berikut:

Tabel 1. Revisi RP Berdasarkan Masukan dari Validator

\begin{tabular}{|c|l|l|}
\hline RP & \multicolumn{1}{|c|}{ Sebelum Revisi } & \multicolumn{1}{c|}{ Sesudah Revisi } \\
\hline $1,2,3$, & - Waktu : 90 menit & - Waktu : $2 \times 40$ ' menit \\
dan 4 & - Kompetensi dasar & - Standar kompetensi \\
& - Hasil belajar & - Tujuan pembelajaran \\
& - Materi prasyarat & - Materi pembelajaran diuraikan \\
\hline
\end{tabular}




\section{B. Deskripsi, Analisis dan Interpretasi Data Hasil Penelitian}

1. Aktivitas Siswa

Aktivitas siswa selama pembelajaran dapat dilihat pada tabel berikut:

Tabel 2. Aktivitas Siswa selama Kegiatan Pembelajaran

\begin{tabular}{|c|c|c|c|c|c|c|}
\hline \multirow[t]{2}{*}{ No } & \multirow[t]{2}{*}{ Aspek yang Diamati } & \multicolumn{4}{|c|}{$\begin{array}{c}\text { Persentase Aktivitas Siswa } \\
(\%)\end{array}$} & \multirow{2}{*}{$\begin{array}{l}\text { Batas } \\
\text { Ideal }\end{array}$} \\
\hline & & $\mathrm{RP}-1$ & RP-2 & RP-3 & $\mathrm{RP}-4$ & \\
\hline 1 & $\begin{array}{l}\text { Mendengarkan } \\
\text { /memperhatikan pen- } \\
\text { jelasan guru/teman }\end{array}$ & 14.38 & 14.06 & 14.69 & 14.38 & $10-20$ \\
\hline 2 & $\begin{array}{l}\text { Membaca/memahami } \\
\text { masalah dalam LKS }\end{array}$ & 10 & 10.31 & 9.69 & 10 & $5-15$ \\
\hline 3 & $\begin{array}{l}\text { Menulis yang relevan } \\
\text { dengan kegi-atan } \\
\text { belajar mengajar }\end{array}$ & 31.88 & 32.50 & 32.19 & 32.50 & $25-35$ \\
\hline 4 & $\begin{array}{l}\text { Mengajukan } \\
\text { pertanyaan kepada } \\
\text { teman/guru yang } \\
\text { berkaitan dengan } \\
\text { materi }\end{array}$ & 11.56 & 11.25 & 11.25 & 11.56 & $5-15$ \\
\hline 5 & $\begin{array}{l}\text { Mengkomunikasikan } \\
\text { hasil kerja kelompok }\end{array}$ & 16.88 & 17.19 & 17.19 & 16.88 & $15-25$ \\
\hline 6 & Mengerjakan kuis & 15 & 14.69 & 15 & 14.69 & $10-20$ \\
\hline 7 & $\begin{array}{l}\text { Perilaku yang tidak } \\
\text { relevan dengan KBM }\end{array}$ & 0.31 & 0 & 0 & 0 & $0-5$ \\
\hline
\end{tabular}

Berdasarkan tabel di atas serta mengacu pada kriteria yang telah ditetapkan pada bab 4 dapat dikatakan bahwa setiap aspek pada RP-1, RP-2, RP-3, RP-4 berada pada kriteria efektif.

2. Pengelolaan Pembelajaran

Data pengelolaan pembelajaran kooperatif tipe STAD pada materi perbandingan berdasarkan data hasil pengamatan pengelolan pembelajaran dapat disimpulkan bahwa pengelolaan pembelajaran oleh guru efektif, karena nilai rata-rata tiap aspek yang diamati menunjukkan pada kategori baik. 
3. Keterampilan Kooperatif Siswa

Keterampilan kooperatif siswa selama pembelajaran dari hasil data di atas berdasarkan deskripsi keterampilan kooperatif siswa selama kegiatan pembelajaran maka diperoleh hasil tiap aspek keterampilan kooperatif siswa berada pada kriteria efektif.

4. Respon Siswa

Data respon siswa dalam mengikuti pembelajaran berdasarkan hasil analisis dapat disimpulkan secara keseluruhan respon siswa terhadap pembelajaran kooperatif tipe STAD positif.

5. Tes Hasil Belajar

Berdasarkan data hasil belajar siswa yang diperoleh secara individu, ketuntasan hasil belajar siswa berdasarkan nilai KKM yang telah ditentukan di SMPN 2 Megaluh yaitu $\geq$ 70 ada 27 siswa tuntas dan 4 siswa tidak tuntas, ketuntasan secara klasikal sebesar $87,09 \%$. Selanjutnya berdasarkan hasil analisis pengolahan data statistik inferensial dengan SPSS untuk uji t sampel bebas, diperoleh hasil t hitung sebesar 2.197 untuk uji dua arah dengan df $=60$ dan taraf signifikan sebesar $5 \%$.

Berdasarkan uji hipotesis yang diajukan, karena $t_{\text {hitung }}>$ $t_{\text {tabel }}$ yaitu $2.197>2.000$ maka Ho ditolak dan Hi diterima. Artinya ada perbedaan hasil belajar siswa pada materi pokok perbandingan antara yang menggunakan pembelajaran kooperatif tipe STAD lebih baik daripada yang menggunakan pembelajaran biasa/konvensional.

\section{Kesimpulan dan Saran \\ A. Kesimpulan}

Berdasarkan hasil analisis data diperoleh kesimpulan sebagai berikut:

1. Penerapan pembelajaran kooperatif tipe STAD efektif pada materi pokok perbandingan untuk siswa kelas VII di SMPN 2 Megaluh Jombang. Dengan memenuhi kriteria (1) ketuntasan belajar secara klasikal tuntas sebanyak 87,09\%, (2) aktivitas siswa efektif (3) kemampuan guru dalam mengelola pembelajaran efektif (4) Respon siswa positif terhadap pembelajaran.

2. Berdasarkan hasil analisis inferensial uji t dengan taraf signifikan $5 \%$ diperoleh $t_{\text {hitung }}=2,197$ dan $t_{\text {tabel }}=2,000$ karena $t_{\text {hitung }}>t_{\text {tabel }}$ maka Ho ditolak dan $\mathrm{Hi}$ diterima, 
artinya hasil belajar siswa dengan pembelajaran kooperatif tipe STAD lebih baik daripada hasil belajar siswa yang mendapatkan pembelajaran biasa di SMPN

\section{B. Saran}

2 Megaluh Jombang tahun pelajaran 2013/2014.

Berdasarkan hasil penelitian ini, untuk guru atau calon guru matematika dapat mengembangkan perangkat pembelajaran kooperatif tipe STAD dan menggunakannya sesuai dengan materi pokok yang lainnya.

\section{DAFTAR PUSTAKA}

Arikunto, S. 2007. Prosedur Penelitian Suatu Pendekatan Praktik. Jakarta: PT. Rineka Cipta.

Adinawan, M.Cholik dan Sugijono. 2006. Matematika untuk SMP/MTs Kelas VII. Jakarta : Erlangga

BSNP. 2006. Standarta Isi Untuk Satuan Pendidikan Dasar dan Menengah. Jakarta

Dimyati dan Mudjiono. 2006. Belajar dan Pembelajaran. Jakarta: Rineka Cipta.

Hudojo, Herman. 2005. Pengembangan Kurikulum dan Pembelajaran Matematika. Malang: Universitas Negeri Malang (UM Press)

Marsigit. 2009. Mathematics For Junior High School. Jakarta: Yudhistira.

Ratumanan, T.G. 2004. Belajar dan Pembelajaran. Surabaya: Unesa University Press.

Sanjaya, Wina. 2013. Penelitian Pendidikan. Jakarta: Kencana Prenada Media Group.

Sugiyono. 2009. Statistika untuk Penelitian. Bandung: Alfabeta

Suprijono, A. 2009. Cooperatif Learning. Yogyakarta : Pustaka Pelajar.

Trianto. 2007. Model-model Pembelajaran Inovatif Berorientasi Konstruktivis. Jakarta : Prestasi Pustaka Publisher.

Trianto. 2009. Mendesain Model Pembelajaran InovatifProgresif. Jakarta: Kencana Prenada Media Group.

Udin S. Winataputra, dkk. 2008. Teori Belajar dan Pembelajaran. Jakarta: Universitas Terbuka. 